\title{
Counseling Service Management in Efforts to Help the Potential Development of High School Students
}

DOI: https://doi.org/10.47175/rissj.v1i3.110

\section{| Muslimah Hikmah Wening, ${ }^{1, *}$ | Enung Hasanah² |}

1,2Deparment of Education Management, Postgraduated Program, Ahmad Dahlan University, Yogyakarta, Indonesia

*muslimahhikmah55@gmail.com

\begin{abstract}
Management of guidance and counseling services means cooperation to determine, implement, and achieve the goals of guidance and counseling services by implementing planning, organizing, staffing, directing, and leadership and controlling. Even though the guidance and counseling service program in schools was aimed at helping students to be able to develop optimally, the fact was that there are still many students who are afraid to go to the GC room just to consult with their GC teacher. It was because there is a negative stigma about GC teachers, namely for students.GC teachers were identical to judges at school because they tend to work to solve the problem of student behavior deviations in schools. This study used a qualitative method. The results showed that the process of guidance and counseling services in private schools in urban areas, the participants carried out several stages of activities as a unit of guidance and counseling service activities. These stages were as follows: (1) orientation stage, (2) planning stage. (3) the implementation stage, (4) the evaluation stage.

KEYWORDS

Management; Services; Guidance and Counseling
\end{abstract}

\section{INTRODUCTION}

The Guidance and Counseling service program in Senior High School is a process of providing assistance to students both individually and in groups in to achieve optimal levels of development and independence (Nkechi et al., 2018), based on the norms prevailing in the society. ( GC for the Guidance and Counseling). This program aims to help students to be able to develop a positive self-identity according to their respective potential (Hasanah et al., 2018; Hasanah et al., 2019). Besides, counseling can help students build social relationships and friendships that can have a positive impact on their lives ( Hasanah et al., 2020).

The education system in Indonesia, guidance and counseling services are one of the educational services that all students must obtain (Undang-Undang Republik Indonesia Nomor 89 Tahun 1989; Peraturan Pemerintah Nomor 28 Tahun 1990; Peraturan pemerintah Nomor 29 Tahun 1990). The existence of these regulations shows that the Indonesian government cares about the development of all students as a whole. In this context, guidance and counseling services can only be carried out by teachers who have a background in counseling or psychology so that their implementation is right on target. Guidance and Counseling services will achieve goals, be right on target, effective and efficient need to be based on management. Guidance and counseling management movements are carried out through intensive communication (Suminingsih, 2019).

Management of guidance and counseling services means cooperation to determine, implement and achieve the goals of guidance and counseling services by implementing planning, organizing, staffing, directing, leadership and controlling. In Counseling Guidance 
management, GC teachers and GC coordinators have made plans that must be implemented, evaluated, analyzed and followed up. Their plans start from basic guidance services consisting of self-understanding and the environment; develop skills for identifying responsibilities; able to handle or fulfill needs and problems, able to develop themselves in achieving life goals, responsive services consist of: individual counseling; crisis counseling; parental, teacher consultation and handover of individual planning cases consisting of: orientation activities; information activities; individual counseling; advocacy and support system/network development such as consultation with teachers; cooperation program with parents and teachers; participate in planning school activities (Ratnawulan, 2016). When school counseling is supported, counselors need new resources and training to support effective and sustainable practices. Future efforts should appeal to school and government leaders by returning the investment that showed through student success academically and more broadly (Knettel et al., 201c9).

When school counseling is supported, counselors need new resources and training to support effective and sustainable practices. Future efforts should appeal to school and government leaders by returning the investment that showed through student success academically and more broadly (Brammer, 1978). Not only problems can be consulted in counseling guidance services, but students can also consult on choosing a secondary school as a career and advice for future direction (Hao et al., 2015). The implementation of guidance and counseling services must be based on the needs and problems of students so that the effectiveness of services will be maximally achieved (Wibowo, 2010). If students are still confused about continuing school, they can do counseling with the counseling guidance teacher. This is a service provided in schools. So the counseling guidance teacher is not only about problems carried out by students but also about student planning who are still confused about the continuation of the learning levels they will take.

Although the program of guidance and counseling services in schools is aimed at helping students to develop optimally, the fact is that there are still many students who are afraid to go to the GC room just to consult with their GC teacher even though GC. This is because there is a negative stigma about GC teachers. For them, counseling teachers are identical to judges at school because they tend to work to solve the problem of student behavior deviations in schools. This occurs in almost all schools in Indonesia, especially in senior high schools located in urban areas.

Based on the results of field observations, it is known that in general, the implementation of GC services in private schools in urban areas of Indonesia, tends to be done to deal with juvenile delinquency problems such as dealing with students' non-disciplinary problems, being late in class and school, smoking. using vape, incomplete attributes, status updates with his girlfriend, frequent online games, or even handling cases of the brawl. Recently, there has been an awareness that the function of GC is not as a school judge, but as a means of helping students to develop optimally, physically, psychologically, and academically. Therefore, GC teachers in private schools located in urban areas and city borders in Indonesia have begun to develop GC service management that can accommodate all student needs, both in the form of preventive and solution service programs. Management of counseling guidance services is very important for the implementation of a quality education process. This requires collaboration and the approach of all stakeholders in schools (Kiweewa et al., 2018).

Discussion on the experiences of counseling teachers in the process of implementing counseling services to help students develop positively is useful for developing practical strategies that are effective in the process. Therefore, it is necessary to have research on the best practices of counseling guidance teacher management in the implementation of 
counseling guidance services to be able to provide information on the way of providing counseling to high school students effectively and efficiently to help students develop their potential optimally. As a guide in conducting this research, the research questions are as follows: How is the management of guidance and counseling services in helping students to be able to develop themselves optimally?

\section{METHOD}

This study used descriptive qualitative method. The reason for choosing this study was to explore the management process of counseling guidance service program management in order to help students develop optimally both their academic and social potential. The accuracy of choosing this method was confirmed by Milles, (2007) that qualitative research is conducted to explore phenomena experienced or known by the subject in depth. This research was a series of activities in obtaining correct data or information and providing a thorough and in-depth understanding about the way counseling guidance teachers carry out counseling guidance services as part of the educational process in helping students develop optimally. The study approach undertaken seeks to describe events and phenomena that occur in the field. The research data generated in this study were written and spoken words. They were spoken explicitly by the participants, also observable participant behavior (Milles, 2007: 15).

Participants in this study were 2. They were guidance and counseling teachers from 2 private high schools in Yogyakarta. The procedure for determining participants was carried out through a purposive sampling method (Etikan, 2016). The criteria for participants were Guidance and Counseling teachers in private schools have experience in BK service management. The entire participant search process had been done agree with social research ethics (APA, 2017) ) and take into account the WMA declaration (2016). Researchers and participants had agreed to keep the personal identities of participants and the school they work for confidentiality. In connection with the social distancing policy, we contacted potential participants for the first time via WhatsApp messages. We also sent an informed consent file containing an explanation of the purpose of the study, as well as the rights of participants in the research process (Langdridge, 2008). In the letter, we stated in writing to comply with social research ethics, researchers will keep all participant personal data confidential and replaced participant names with code $\mathrm{P}$ ( $\mathrm{P} 1$ for the first participant, and P2 for the second participant).

The data collection process was carried out through online interviews related to the implementation of counseling guidance teacher management in the implementation of counseling guidance services. Each teacher was interviewed for 40-60 minutes. In the following, we presented a list of the main questions in our interview introduction:

1. What is the preparation process for the implementation of counseling guidance services that you have done at school?

2. Tell about the process of implementing counseling guidance services carried out by the ladies/gentlemen at school? What are the top priorities in the BK service program at your school?

3. How counseling teachers carry out a structured evaluation of the counseling guidance program?

After the data hadd been collected, it was analyzed using the Analysis Interactive model from Milles, 2007: 169. In detail, the data analysis techniques used in this study are: 1) data collection by classifying, disposing of data from interviews and observations that are not needed, and organizing the data. so that conclusions can be drawn and verified. The data classification that was considered relevant and necessary as a result of this study was data 
that agree with the research question. 2) the data display in this study was in the form of a brief description based on the results of the interview. 3) verification. The next step was to conclude. Conclusion or verification was the final activity of this research. In this verification process, the researcher re-checks all collected data, its suitability with research objectives, and finally makes decisions about which data can be used as research results.

\section{RESULTS}

Based on the results of interviews with participants, it was known that in the process of implementing the management of guidance and counseling services in private schools in urban areas, the participants carried out several stages of activities as a unit of guidance and counseling service activities. These stages are as follows: (1) orientation stage, (2) planning stage. (3) the implementation stage, (4) the evaluation stage The stages can be explained in detail as follows:

\section{Orientation stage}

This stage was the basic stage of the entire process of guidance and counseling services to help develop the potential of students optimally. At the beginning of the new school year, the guidance and counseling teachers oriented students' potential to find out how the student's condition was viewed from an academic and social perspective. These data were the initial capital for teachers to be able to compile a counseling guidance service program that will be provided. There were various ways that are done by the participants to capture the initial data of students at the beginning of the semester. One of them was done by P1 who did data collection through the school introduction program and used manual data collection instruments. The following was P1's statement regarding this matter:

"Nah After the new student enters the school, the BK teacher provides orientation services in the form of an introduction to the school environment and then the conditions of the school, how will the school be so that the new students can adapt to knowing the school environment more or less like that. And later students can adapt to the school environment" (P1, lines 13-17)

P1 also stated that at the school where he worked, an IQ test had not been carried out. P1, who is the only BK teacher in his school, also did not provide career guidance and talent development services. P1 stated: "So far I have not used information services regarding student interests and talents". P1 only focused on the problem of dealing with the problematic behavior of students who are quite heavy.

Another participant, namely P2 who came from a different school from P1, also gave a similar explanation about the initial process carried out by the teacher before planning, namely conducting orientation and assessing students' initial data. The process began by looking for data about the students' initial conditions. In the school where P2 teaches, there were several BK teachers because the number of students is large, so the assessment process was carried out by conducting a mass psychological test at the beginning of the school year. The goal was to make it easier for guidance and counseling teachers to provide assistance and direction to students. The following was the $\mathrm{P} 2$ statement regarding the initial orientation process to obtain student initial data at the beginning of the school year:

"In our school there are $3 \mathrm{BK}$ teachers, so we share jobs. At the beginning of the school year, at our school we routinely carry out interest aptitude tests for students to detect the potential and problems faced by students to develop themselves well. We use these data to formulate what programs are more 
suitable for us to implement in order to help students become successful students academically, career and socially" (P2, lines 11-17).

\section{Planning Stage}

After the participants conducted data assessment [orientation], they then developed a counseling guidance service plan based on student needs. In the GC service program, teachers formulate various strategies that they will implement in serving students. This can be seen from the participant's statements as follows:

"Nah in work programs make schedules for classical and group guidance and others. according to schedule and later can be delayed, later you can change the schedule. Because we did not enter the class, so yes, we carry out the service by observing the conditions first" (P1, lines 18-21).

P2 described the same thing regarding the use of assessment data to develop service programs. However, P2 was more detailed and explained the links between student data, programs, and religious values that he developed:

"The results of surveying the initial data, then we sorted out which ones required higher social, academic or career concerns. We classify students based on their individual needs, then compile a service program and schedule for individual and classical meetings. Emmmm...yes... we also considered what values to emphasize the children in building their character." (P2, lines 20-24)

The counseling guidance service program prepared by the participants was a comprehensive program. They not only highlighted academic matters but also paid attention to various factors related to the success of students' education in general.

Even though the form of the program covered all aspects of student life, P1 said that he was more likely to handle cases of behavioral deviation than career or achievement direction. This was because most of the students are broken home children. "Most of the students' problems were about their parents because many of my students had both parents broken home" (P1, lines 30-31).

$\mathrm{P} 2$ statement tended to be different regarding the main program in the school where he works. P2, who teaches at a school known as a leading private school, said that in general the counseling service program carried out by him is career services, although the service program was structured to respond to all aspects. In this case P2 stated the following:

"We have prepared a variety of programs to serve the needs of students, but based on the results of assessing data, students at our school need more career guidance. They are confused after graduating from high school what to do? It is better to take courses to get more skills if they have graduated .... yes .... like that in our school. So our program is more flexible." (P2, lines 37-40)

Although the data collection process and the types of programs planned by the participants differed in their implementation, all schools had almost the same types of programs. Below is presented table 1.1 to show the content of service programs generally created by the participants:

Tabel 1. Comprehensive GC

\begin{tabular}{|c|l|l|}
\hline No & \multicolumn{1}{|c|}{ Kinds of Service } & \multicolumn{1}{c|}{ Forms of service } \\
\hline 1. & Basic Service & Classical service \\
\hline
\end{tabular}




\begin{tabular}{|c|c|c|}
\hline & & Group service \\
\hline & & Collaboration with homeroom teacher \\
\hline & & Collaboration with parents \\
\hline & & Orientation service \\
\hline & & Information service \\
\hline & & Content mastery service \\
\hline 2. & Responsive Service & Consultation service \\
\hline & & Individual counseling service \\
\hline & & Group counseling service \\
\hline & & Referal (case handler) \\
\hline & & Peer counseling \\
\hline & & Mediation service \\
\hline 3. & Individual Planning Service & Individual/group assessment (evaluation) \\
\hline 4. & System support & Professional development \\
\hline & & Penilaian konsultasi dan kolaborasi \\
\hline & & $\begin{array}{l}\text { Program management: } \\
\text { a. Job development } \\
\text { b. Data management and collection } \\
\text { c. Activity plan } \\
\text { d. Time setting } \\
\text { e. Calendar (yearly, semester, monthly, } \\
\text { and weekly) } \\
\text { f. Activities schedule } \\
\text { g. Budget } \\
\text { h. Facility setup } \\
\text { i. Organization dan personnel } \\
\text { j. Control }\end{array}$ \\
\hline
\end{tabular}

(Source:compilation of in-depth interview)

\section{Implementation stage}

Although the types of programs in the three schools were relatively the same, each school had different strategies and emphases, depending on the needs of their respective learners. This could be seen from the explanations of the participants regarding the practice of implementing GC services in their respective schools. One example was the school where P1 works, was different from other schools. Its the conditions of the school and students were different. P1 who teaches in a private school with a relatively small number of students said that he still paid attention to various elements regarding what needs to be considered in providing counseling services, but tended to serve individual services more often. Here was the statement:

"Yes provides individual and group counseling services. So usually with this service, there are usually students who come to the counseling teacher's room personally and I also call them. Because if I don't call the children, they won't come to the BK room to tell their various problems. Because with me calling these students, I will find out that various kinds of students experience many problems and if I do not call them to the BK room, the individual and group counseling services will not work." (P1, lines 24-29) 
The strategy carried out by $\mathrm{P} 2$ is slightly different from that carried out by $\mathrm{P} 1$. P2 admitted that during the process of providing counseling services to students, he often provided services to small groups. In addition to providing counseling services to small groups, P2 also provided individual assistance and services. The school, where P2 works, has room facilities and complete counseling facilities so that the implementation of counseling services for students becomes more organized and effective. This condition is different from the existing facilities in the school where P1 works.

Although each school had different strategies in providing guidance and counseling services, it could be seen that there is a similar pattern in the implementation of GC services, that classical learning is only carried out when the school has special activities. In detail, the implementations of GC services is as follows:

1. Basic guidance services in schools consisted of classical guidance and individual guidance. According to P1, schools only calculated the capacity and performance of BK teachers based on the number of students served so that the form of service is left to teachers who are considered to know better. In this context, group guidance is not scheduled regularly, but is carried out at certain times. On certain occasions, the classical service process sometimes is carried out. It was carried out during breaks with the field observation process. Collaboration with the homeroom teacher is carried out using the WhatsApp group. If there are students who have handlers to find out about the problem, ask the homeroom teacher so that they collaborate. Collaboration with parents was also carried out by calling parents through WA group school letters as well. Orientation services carried out when new students entered the school giving advice. Information services applied in school can run well from classical and group guidance even though it is not scheduled. Content implementation, placement, and distribution services exist to provide information about school continuation for students who are still confused. Content services used school material.

2. Responsive guidance services as follows: consulting services provide consulting services by calling students, there were still many students who are afraid to be called by the GC teachers. Individual and group counseling services and how to assess the results and processes are also provided. The results and process of the guidance and counseling teachers were seen on how the students are active and how the student consultation runs in the grades for evaluating the results of the student consultations that have been carried out. Referral service (case handing) was carried out, for example, cases of sick children brought to the doctor. Mediation services in cases of children fighting. Peer counseling services for student training are trained with fellow students, there is no BK teacher.

3. Individual planning services. There is program evaluation, which is an evaluation of results and the program into a good planning. There is MGB, on of the example of support systems, who participated in Seminar. Providing collaborative consultations could be the collaboration with homeroom teachers, school principals, administrative staff by providing handlers in asking the principal and homeroom teacher. The first program management was complete data collection management, the second was an activity plan for a work program, the third was time arrangements are in the work program mentioned, the fourth was calendars (annual, semester, monthly, weekly) which were in the program, the fifth activity schedules were in place, the sixth budgets were in place, The seventh preparation of facilities was there, but it was less than ideal for each school, indeed the BK classrooms were on average less than ideal, the eight organizational boards exist, the ninth was about controlling. 
The teacher also made counseling guidance programs in schools with several services that have been made by the teacher. Not only making the program but also making work programs. The implementation was done in groups because there are no class hours to carry out classical guidance. The teacher also sometimes called students to carry out counseling guidance. Evaluation is also carried out in sequence and coherently by providing evaluation results of students who carry out consultations to counseling guidance teachers.

\section{Evaluation stage}

GC evaluation activities were carried out by making a GC activity report which is carried out in the form of process evaluation and evaluation of results and also follow-up of these activities. The counselor was evaluated by the principal and supervisors from the Dikdasmen. At this stage, the participants admitted that the evaluation of their BK services was carried out in various ways by using 2 evaluations, namely evaluation of assessments and understanding. Both types of assessment are more qualitative in nature. P1, for example, he stated that the evaluation of the assessment was an attempt to assess the extent to which the service was implemented. It was aimed to achieve the stated goals and evaluation of understanding, namely the process of knowing the extent to which students understood the counseling process they had carried out.

\section{DISCUSSION}

Based on the results of the research, it was obtained several stages of activities were carried out as a unit of guidance and counseling service activities. The stages obtained in this study are: (1) the orientation stage, (2) the planning stage, (3) the implementation stage, (4) the evaluation stage, and (5) the follow-up stage. As a teacher, these stages need to be implemented so that they can be applied according to the teacher's ability to fix and guide students in schools according to the real goals of education (Handayani, 2017). The details of the stages are as follows:

1. Orientation stage

The initial action taken by the participants was to orientate. Orientation and exploration of data for GC teachers are useful for introducing the school environment so that students know the school environment. School environmental orientation services also allow students to know, understand, and adapt to new environments, especially the school environment (Basmalah et al, 2016). In addition to introducing the school environment, orientation is also used to provide discipline in schools. The main purpose of discipline material orientation services can be used to discipline students, this is agreed with research (Sutrisno, 2017) that orientation services are proven to improve student discipline. As a basic stage of the process of guidance and counseling services to help students develop optimally. Providing information services regarding GC orientation can help students understand their developmental tasks, understand problems that often arise due to suboptimal development by utilizing guidance and counseling services (Mualimah, 2013).

The implementation of self-development orientation services is a group where there are bonds between children of the same age. Matters related to behavior, interests, attitudes, including the thoughts of adolescents who are heavily influenced by their group friends, in addition to the influence of parents, parents will not be worried if their children associate with the implementation that is developing in the community (Wahyudi, 2018).

2. Planning Stage 
The planning in both schools is neatly structured which includes annual programs, semester programs, weekly programs, and syllabus. In the BK service program, teachers formulate various strategies that will be carried out in serving students. the programs that have been made by the GC teachers are comprehensive. The procedures for composing a comprehensive guidance and counseling program are planning, organizing, implementing, and evaluating. This program is based on efforts to achieve developmental tasks, develop potential, and solve counselee problems (Bhakti, 2017). Besides that, it also pays attention to various factors related to the success of students' education in general. According to (Kurniawan, 2015) this comprehensive guidance and counseling service program as a service that has systematic advantages is not just a systematic program that is very suitable to be developed in high school..

3. Implementation Stage

The implementation of counseling guidance services was in different schools, but it has the same goal of helping students. The service is individual or group. The actualization of the implementation of guidance and counseling activities needs to be realized that it is different from teachers in other fields of study who have been scheduled in detail and clearly, whereas in counselors activities can be carried out inside and outside the classroom so that the counselor is required to be able to allocate activities in the classroom and in the classroom. outside the classroom so that activities run well and can achieve predetermined goals (Su'ainah et al., 2017). The handling of the first problem is carried out by the GC teacher and collaboration with the homeroom teacher if the counseling teacher is not capable it will be coordinated with the deputy principal. If the deputy principal is incapable then it will be handed over to the principal by holding a case conference attended by all BK teachers, guardians class, vice-principal, and principal.

4. The evaluation stage

Evaluation is the most important activity in GC program management. Without evaluation, it is impossible to know and identify the success of the implementation of the GC program that has been planned (Rachmawati et al., 2013). GC evaluation activities in high school counseling teachers make a report on GC activities which are carried out in the form of process evaluation activities and evaluation of results and also follow-up of these activities. The counselor is evaluated by the principal and supervisors from the Dikdasmen. The counselor is evaluated on the appropriateness of the program, administrative data collection, room facilities, and GC report. Assessment of guidance and counseling activities in schools is all efforts, actions or processes to determine the degree of progress quality in activities related to the implementation of the Counseling Guidance program by referring to certain criteria or benchmarks in agree with the Counseling Guidance program that is carried out (Azizah et al., 2017).

\section{CONCLUSION}

Based on the results of the research, it was obtained several stages of activities were carried out as a unit of guidance and counseling service activities. The stages obtained in this study are: (1) the orientation stage, (2) the planning stage, (3) the implementation stage (4) the evaluation stage, and (5) the follow-up stage. This research is just an exploration stage in terms of the implementation of counseling services for high school children whose schools are located in urban areas of Indonesia. There has been no in-depth study of how the effects of each work program they have implemented, both on students and teacher development. Further research is needed to gain a broader understanding of the counseling implementation 
services and its relationship with the optimal development of character and students' potential.

\section{ACKNOWLEDGMENT}

The researcher would like to thank to the great academic consultant and participants. Thanks to your support because this article can be completed.

\section{REFERENCES}

APA. (2017). American Psychological Association. Ethical Principles of Psychologists and Code of Conduct. American Psychologist Aaaociation, 57(12), 1-20. https://doi.org/10.1037/0003-066X.57.12.1060

Azizah, F., Ginting, H. F. B., \& Utami, R. S. (2017). Evaluasi Pelaksanaan Program Layanan Bimbingan dan Konseling di Sekolah. Prosiding Seminar Bimbingan Dan Konseling, 1(1), 177-188.

Basmalah, B., Endang, B., \& Lestari, S. (2016). Pengaruh Layanan Orientasi Terhadap Penyesuaian Diri Dalam Kegiatan Belajar Di Sekolah. Jurnal Pendidikan Dan Pembelajaran Khatulistiwa, 5(10), 1-12.

Bhakti, C. P. (2017). Program Bimbingan Dan Konseling Komprehensif Untuk Mengembangkan Standar Kompetensi Siswa. JURKAM: Jurnal Konseling Andi Matappa, 1(2), 131. https://doi.org/10.31100/jurkam.v1i2.63

Brammer, L. M. (1978). The making of a dutch school counselor: One American's perspective. International Journal for the Advancement of Counselling, 1(2), 172-188. https://doi.org/10.1007/BF00120928

Etikan, I. (2016). Comparison of Convenience Sampling and Purposive Sampling. American Journal of Theoretical and Applied Statistics, 5(1), 1. https://doi.org/10.11648/j.ajtas.20160501.11

Handayani, S. (2017). Optimalisasi Peran Bimbingan Konseling Di Sekolah. Jurnal Pemikiran Pendidikan, 19(2), 33-49.

Hao, D., Sun, V. J., \& Yuen, M. (2015). Towards a Model of Career Guidance and Counseling for University Students in China. International Journal for the Advancement of Counselling, 37(2), 155-167. https://doi.org/10.1007/s10447-015-9234-7

Hasanah, E., \& Supardi, S. (2020). The Meaning of Friendship in The Process of SelfIdentity Development for Indonesian Adolescents. Journal of Social and Political Sciences, 3(1). https://doi.org/10.31014/aior.1991.03.01.160

Hasanah, E., Zamroni, Z., Dardiri, A., Indartono, S., \& Supardi, S. (2018). Literature Review of Parenting Style to Support the Development of Adolescent Identity. Asian Social Science, 14(6), 157. https://doi.org/10.5539/ass.v14n6p157

Hasanah, E., Zamroni, Z., Dardiri, A., \& Supardi, S. (2019). Indonesian Adolescents Experience of Parenting Processes that Positively Impacted Youth Identity. The Qualitative Report, 24(3), 499-512.

Kiweewa, J. M., Knettel, B. A., \& Luke, M. M. (2018). Incorporating Comprehensive Counselling and Guidance Models into School Curricula in Sub-Saharan Africa. International Journal for the Advancement of Counselling, 40(2), 133-147. https://doi.org/10.1007/s10447-017-9316-9

Knettel, B. A., Luke, M. M., Kiweewa, J. M., Nsubuga, H., Darkis, J. T., Afriyie, O., \& Ojiambo, D. (2019). Stakeholder Perspectives on School-Based Guidance and Counseling in Uganda : Emerging Priorities for Student Support and Teacher Training. International Journal for The Advancement of Counselling.

Kurniawan, L. (2015). Pengembangan Program Layanan Bimbingan Dan Konseling 
Komprehensif Di Sma. Jurnal Psikologi Pendidikan Dan Konseling: Jurnal Kajian Psikologi Pendidikan Dan Bimbingan Konseling, $1(1), 1$. https://doi.org/10.26858/jpkk.v1i1.1351

Langdridge, D. (2008). Phenomenology and Critical Social Psychology: Directions and Debates in Theory and Research. Social and Personality Psychology Compass, 2(3), 1126-1142. https://doi.org/10.1111/j.1751-9004.2008.00114.x

Milles, Mathew B, and A. M. H. (2007). Qualitative Data Analysis. Jakarta: UI Press.

Mualimah, S. (2013). Penerapan Layanan Informasi Mengenai Orientasi BK Untuk Meningkatkan Minat Dalam Memanfaatkan Layanan BK Siswa Kelas XI Di SMAN 1 Balen Bojonegoro. Jurnal Mahasiswa Bimbingan Konseling, 01(01), 186-192. https://doi.org/10.1017/CBO9781107415324.004

Nkechi, E. E., Ewomaoghene, E. E., \& Egenti, N. (2018). The Role of Guidance and Counselling in Effective Teaching and Learning in Schools: The Cameroonian Perspective. International Journal of Multidisciplinary Studies, 1(2), 11-15. https://doi.org/10.20448/2003.11.11.15

Peraturan Pemerintah Nomor 28 Tahun 1990

Peraturan Pemerintah Nomor 29 Tahun 1990

Rachmawati, U., Nusantoro, E., \& Kurniawan, K. (2013). Manajemen Bimbingan Dan Konseling Tanpa Alokasi Jam Pembelajaran Di SMA 3 Semarang. Indonesian Journal of Guidance and Counseling, 2(1), 55-61.

Ratnawulan, T. (2016). Manajemen Bimbingan Konseling Di SMP Kota Dan Kabupaten Bandung. EDUKASI, 2(1), 1-17.

Su'ainah, Aliman, \& Juarsa, O. (2017). Manajemen Bimbingan dan Konseling Di SMA. Manajer Pendidikan, 11(3), 287-295.

Suminingsih. (2019). Manajemen Layanan Bimbingan dan Konseling dalam Upaya Meningkatkan Mutu Belajar Pendahuluan. 1(1), 131-143.

Sutrisno, T. (2017). Tri Sutrisno. Jurnal Pendidikan Ibtidaiyah, 1(2), 1-8.

Wahyudi, M. D. (2018). Pengaruh Layanan Orientasi Terhadap Pengembangan Diri Siswa Kelas Viii Smp Negeri 1 Salapian Tanjung Langkat Tahun Pelajaran 2016/2017. Jurnal Serunai Administrasi Pendidikan, 6(2), 26-35. https://doi.org/10.37755/jsap.v6i2.48

Wibowo, A. (2010). Tingkat Efektifitas Dan Himpunan Data Di SMA N egeri 1 Metro Tahun Pelajaran 2009 / 2010. 35-50.

WMA. (2016). Annexe 2. WMA Declaration of Taipei on ethical considerations regarding health databases and biobanks. Journal International de Bioéthique et d'éthique Des Sciences, 28(3), 113. https://doi.org/10.3917/jib.283.0113 